\title{
Healthy Lifestyle During The Pandemic Through Sport Activities
}

\author{
Faradina Safira Andriyanti ${ }^{1}$, Fatikha Sofia Iqlima ${ }^{2}$ \\ \{faradinasafira09@students.unnes.ac.id ${ }^{1}$, fathikasofia1903@students.unnes.ac.id ${ }^{2}$ \} \\ Universitas Negeri Semarang, Indonesia ${ }^{1,2}$
}

\begin{abstract}
Maintaining an ideal body weight during a pandemic like this is very difficult, especially when the government recommends staying away from crowds and reducing unnecessary activities outside the home. So, everyone's healthy lifestyle is affected, like untreated food. A lot of appetite increases the width of a person's body, especially if it is not balanced with exercise. Aim to maintain a healthy lifestyle by eating nutritious foods, avoiding stress, exercising regularly, and getting adequate rest. When a pandemic occurs, preventing the Covid-19 virus requires self-awareness by complying with health regulations, namely washing hands with soap, wearing masks, and maintaining distance. Physical exercise also supports sports by training endurance, speed, frequency, intensity, agility, flexibility, balance, coordination and timing. The result of literature review is that the number of target characteristics in this case usually occurs in sportsmen, children, and the elderly.
\end{abstract}

Keyword: Healthy lifestyle, Pandemic, Physical exercise, Characteristics

\section{Introduction}

Maintaining an ideal body weight in times of a pandemic like this is very difficult, moreover the government recommends staying away from crowds and reducing nonessential activities outside the home. Everyone needs to adopt a healthy lifestyle by maintaining cleanliness, exercising, eating nutritious food and getting adequate rest. Especially during a pandemic like this, all people in the world, especially Indonesia, are required to pay more attention to their own health. The case of Covid-19 in Indonesia has shocked the public and caused fear from various circles [1]. Covid-19 is a disease caused by the SARS CoV-2 virus with general symptoms of both mild and severe acute respiratory disorders including fever, cough, shortness of breath, fatigue, runny nose, sore throat and diarrhea. In general, this virus transmission occurs through droplets or body fluids that are splashed on a person or objects around them that are 1-2 meters away through coughing and sneezing. The government recommends staying indoors if there are no very important activities.

Health is a prosperous state of body, soul, and social, which enables everyone to live productively socially and economically [2]. If the healthy body will feel fresher, doing activities for a long time will not be felt. Maintain a healthy lifestyle from the food consumed, namely nutritious and clean food. If the food is guaranteed, the body will easily digest it properly. Exercise regularly, three times a week. Sport as a physical activity plays an important role in improving one's physical fitness and maintaining an ideal body weight. 
Physical fitness can be maximized through the fulfillment of balanced nutrition. Adequate rest, sleep approximately 6 to 8 hours.

Among the parents, children and even athletes must have problems in terms of weight. This is because when the government implements lockdown regulations, people tend to carry out monotonous and limited activities. Thus, it causes boredom and activities such as playing cellphones, watching television, and eating are not controlled. Most people feel this way and eventually, they gain weight. To stop this problem, we can do sports activities at home that can help the body from getting wider. An athlete must feel the same way. So that the body does not expand, then do sports activities even if only at home.

Regular exercise is one way to maintain a healthy lifestyle, don't forget to try to keep your body fresh and happy. Because this can increase the dopamine hormone which acts as the body's defense system. Exercise is very important to do during the Covid-19 pandemic so that the body remains in shape and maintains an ideal body weight. Training activities that can be carried out include; resistance training, speed training, agility training, flexibility training, balance training, and coordination. A good degree of health is able to create a healthy body condition and quality human resources.

The goal of maintaining a healthy lifestyle with physical exercise also supports resistance training, speed, intensity, agility, flexibility, balance, coordination and time so as to improve physical fitness during this pandemic. The body also does not increase in width and body weight can remain ideal.

\section{Methods}

Library Research the method used in the preparation of this article is the library research method, which is to search for books, documents, internet sources and other references that are relevant to the issues discussed in this discussion. Read from these sources, cited materials that are important and what is sought, then summarized, and compiled into a writing. Website Study (internet study) is a technique of collecting data or materials by searching through existing websites, with the help of a network or internet connection. Unfortunately, studies conducted by means of websie studies or internet studies, depend on the presence or absence of an internet network. In addition, this website or internet study depends on the strength or weakness of the internet network. Even though the presence or absence of the internet and the strength or weakness of this internet network in each region in Indonesia varies. Literature Study aims to make it easier for readers to find references in the bibliography. Especially in conducting studies on healthy lifestyles with publish applications, and mendeley desktop.

\section{Result and Discussion}

Health is one of the basic needs of society, so health is a right for every citizen protected by the Constitution [3]. Every country recognizes that health is the biggest asset to achieve prosperity. Maintaining an ideal body weight during a pandemic like this is very difficult, especially when the government recommends staying away from crowds and reducing unnecessary activities outside the home. So, everyone's healthy lifestyle is affected, like untreated food. A lot of appetite increases the width of a person's body, especially if it is not balanced with exercise. Maintain a healthy lifestyle by eating nutritious foods, avoiding 
stress, exercising regularly, and getting enough rest. When a pandemic occurs, preventing the Covid-19 virus requires self-awareness by complying with health regulations, namely washing hands with soap, wearing masks, and maintaining distance.

Physical exercise also supports sports by training endurance, speed, frequency, intensity, agility, flexibility, balance, coordination and timing. The number of characteristic targets in this case usually occurs in sportsmen, children, and the elderly. Physical exercise also supports sports by training endurance, speed, frequency, intensity, agility, flexibility, balance, coordination and time. Physical exercise can be in the form of work out at home, with back ups, push ups, sit ups, yoga, jumping rope, and so on. Exercise is defined as a systematic exercise activity that is repeated over a long period of time accompanied by a gradual and continuous increase in load according to each individual's ability, the goal is to form and develop physiological and psychological functions [4].

Not only parents and athletes, but the elderly must also apply light sports activities and often bask in the sun for about 10 minutes to be healthier. As we know that the elderly are susceptible to the Covid 19 virus, therefore it is recommended to take care of their elderly parents. Gaining weight if you want to lose back is very difficult.

The cause of a person not maintaining a healthy lifestyle is too stressful, does not maintain his eating habits, is lazy to exercise and stays up late too late. When we want to maintain a healthy lifestyle, especially in the current pandemic era, which are vulnerable to viruses. Supposedly by paying attention to dietary patterns, exercise training and health protocols.

At this time many people have a poor lifestyle, especially in their diet, sleep, and exercise incorrectly. Eat without care about the nutritional content in these foods, or vice versa because you want to lose weight body, eat less because you want to get your ideal body weight quickly. Maintaining a diet is very important so that we can adjust it according to the needs of the body. Apart from maintaining a diet, another important thing is doing sports activities [5]. Moreover, in Indonesia there are many fast food, so people at home can order food through the grabfood application or the like.

Increasing age also tends to be followed by the emergence of various chronic diseases, not a few elderly who have chronic diseases, such as heart disease, diabetes, asthma, or cancer With fast food it is not good to be consumed continuously [6]. It is true that the government recommends staying at home, but must maintain a nutritious diet. For the elderly themselves, the immune system is vulnerable to Covid 19 , so it must be maintained. As a child, they have to take care of their parents to be diligent in exercising lightly and keeping up with nutritious foods.

One of the diseases that is currently endemic is the novel coronavirus or often called the corona virus. There are at least two types of coronavirus that are known to cause diseases that can cause severe symptoms such as Midle Eas Respiratory Syndrome (MERS) and Severe Acute Respiratory Syndrome (SARS). Coronavirus Disease 2019 (covid 19) is a new type of disease that has never been previously identified in humans. The virus that causes covid 19 is called sars-cov-2. Corona viruses are zoonotic (transmitted between animals and humans). Common signs and symptoms of covid 19 infection include symptoms of acute respiratory problems such as fever, cough and shortness of breath. The average incubation period is 5-6 days with the longest incubation period of 14 days. In severe cases of Covid 19 it can cause pneumonia, acute respiratory syndrome, kidney failure and even death. A healthy lifestyle is a person's effort to keep his body healthy. Most of them think that a healthy lifestyle is a difficult lifestyle to live. Sports activities that are recommended to maintain health are physical fitness activities [7]. 
Indonesian Community Lifestyle During Covid-19. Lifestyle is a habitual pattern of a person as reflected in his daily activities, interests and opinions. The way a person interacts with their environment is reflected in their lifestyle. A healthy lifestyle is a choice from a lifestyle that is carried out by a person [8]. Healthy lifestyle recommended during the Covid19 pandemic include: (1) consumption of high protein foods every day; (2) daily consumption of fresh fruits and vegetables; (3) drink water not less than $1500 \mathrm{~mL}$ every day; (4) adopting a diverse diet of various types, colors and sources. (5) Consumption of adequate nutritional intake; (6) if malnourished, take supplements; (7) regular rest for at least 7 hours per day; (8) exercise routine.

Life during the Covid-19 pandemic requires humans to spend a long time every day at home. A person who has a static lifestyle can interfere with the body's immune system which can cause various diseases, both non-infectious (degenerative) and infectious. Efforts to prevent the spread of Covid-19 can be done by improving the physical quality of the body. The frequency of doing sports activities every week can affect the performance and ability of a person's physical condition. The low level of a person's activity can have a negative impact on physical fitness. The negative impact of low fitness levels is that the body becomes tired quickly, is overweight, and is prone to symptoms of sedentary disease. Fitness is very important to support someone in carrying out their daily activities without experiencing excessive fatigue [9].

On the other hand, excessive or strenuous sports activities can reduce immunity or immunity. Clinical immunity deficiency occurs due to the combined effect of several small changes in several immune parameters. Small changes in immune parameters can cause a resistant/ immune effect against minor diseases, for example in upper respiratory tract infections. Exercise has both positive and negative effects on immune function and susceptibility to disease incidence. A study states that someone who does light exercise can improve immune function, increase immunity levels, and last for a long time. Meanwhile, very intensive/ excessive sports activities will be able to interfere with immune function or cause immune suppression.

To avoid contracting the Covid-19 virus, the Government has appealed to the public to always maintain cleanliness and lead a healthy lifestyle. A healthy lifestyle is by maintaining immunity by exercising based on FITT (Frequency, Intensity, Time, and Type). People are also advised to maintain nutritional intake and hydration. In addition, people are also advised to pay attention to body recovery because a tired body will be susceptible to various kinds of viruses and diseases.

Virtual socialization about healthy cultural behavior to the public of students and their families living in rural areas has been well organized and is in accordance with the protocol for preventing the transmission of Covid-19. Awareness and discipline to practice a culture of healthy living must continue to be built and implemented [10]. Good living habits need to be managed routinely so that they become a lifestyle that is settled for each individual. Consistency is the most important thing to maintain survival and productivity together in this pandemic.

Therefore, in times of pandemic, such as maintaining a healthy lifestyle is very important. Physical exercise :

\section{The Concept of Fitness}

1. Definition of Muscle Strength

The definition of fitness is the ability of a person to carry out activities or daily work effectively without causing significant fatigue and still be able to carry out subsequent activities in good condition and still be able to enjoy their spare time. 
Individual fitness includes physical fitness, mental fitness, emotional fitness, and social fitness (total fitness). There are three levels of fitness: static fitness, dynamic fitness, motor fitness

2. $\quad$ Fruit Tip

Eating (nutritious), Rest (quality) and Exercise (regular)

\section{Basics of Fitness Training}

1. Defininition of Fitness Exercises

The definition of fitness training is a systematic training process using movements aimed at improving or maintaining the quality of body functions which include fitness components.

2. Principles of Fitness Exercise

SPORT (Specific, Progressive, Overload, Riversible, Training Effect).

3. Tages of Fitness Training

Warming up, Conditioning and Calming.

4. Fitness Exercise Measures

FIT (Frequency, Intensity, Time).

Method of Fitness Exercise

1. Baic Methods of Fitness Training MOLIS (Move / move, Lift / lift, Strech / stretch).

2. Method of Fitness Training

Cardiac endurance training methods (definition, characteristics, exercise dose, model, training program). Methods of strength and endurance training (definition, characteristics, exercise measure, training model, training program). Methods of joint flexibility training (understanding, characteristics, exercise measures, training models, training programs). Methods of body composition training (understanding, characteristics, training rates, training models, training programs).

\section{Planning of Fitness Exercises}

1. Periodicity of Fitness Exercises

Period of diagnosis, The grounding period, The period of improvement and Maintenance period.

2. Fitness Service Flow

Medical history and lifestyle screening, Health and fitness checks, Formulation of training programs (training objectives, program priorities, selecting training models, selecting training tools), The training process and Evaluation of exercise results.

\section{Measurement of Fitness Status}

1. Measurement of Heary Lung Resistance Treadmill running test, 12 Minute Running Test, Run $2.4 \mathrm{~km}$ and Multistage fitness test.

2. Measurement of Muscle Strength and Durability Muscle Strength (1 RM Test) and Muscle Endurance (Push-Up Test).

3. Measurement of Joint Flexibility

Reach Sitting Test (flex the hip joint) and Leg Lift Test

4. Measurement of Body Fat

Body Fat Thickness Test with Fat Caliper (biceps, triceps, suprailliaca and subscapula). 


\section{Exercise Measures}

1. Exercise frequency : 3-5 times/week

2. Exercise intensity : $75-85 \%$ maximal heart rate (old age starts $60 \%$ continue to increase)

3. Time (training duration) : 20 - 60 minutes without stopping

Training Model

Continuous modeling (jogging on the court / on the treadmill, cycling on the field / stationary, swimming, rowing, aerobics) etc. football, badminton, tennis.

\section{Exercise Methods for Muscle Strength and Durabilty}

Muscle strength is the ability of a group of muscles to resist the load in one effort. ex. the ability of the arm muscles to lift the chair. Muscle endurance is the ability of a group of muscles to carry out a series of work for a long time ex. the ability of the arm muscles to move the chair from a certain place to another at the same time and a considerable distance.

Exercise measure are carried out 1-8 reps, 3-5 sets, rest 2 - 5 minutes.

Training model own weight ex : sit ups, push ups etc, real weights : free machine / gym machine and free weight / dumple, barbell etc and several weight training systems to train muscle fitness: system sets, super sets and compound sets.

\section{Joint Exercise Methods}

Flexibility is the ability of the joints to move freely. Quality of flexibility is influenced by joint structure, quality of muscles, tendons and ligaments, age, temperature, etc. Flexibility of joints affects a person's mobility \& work dynamics. Flexibility is synonymous with long life.

Exercise measures, frequency: can be done every day, intensity: a measure of the intensity, the limit of pain and pain in the muscles and time: $4-30 \sec$ (Rep: 1- 3 repetitions)

Training model, static streching, dynamic streching

\section{Body Composition exercise Method}

Body composition is the ratio of body weight consisting of fat to lean body weight. Normal body fat for men $15-20 \%$, Normal body fat for girls $20-25 \%$.

Exercise measures frequency: 3-5 times / week, intensity: 65 - 75\% max. Heart rate and time: 20 - $60 \mathrm{mt}$.

Training model, jogging, cycling, aerobics, swimming etc. There will be changes after 3 months of training.

With the routine exercises described, the body will experience changes in muscles, joints, and others. To maintain a healthy lifestyle, especially for children, exercise can be done at home during the pandemic with light exercise in order to maintain the ideal body towards a healthy lifestyle. Moreover, the special training for athletes will be different from ordinary people. Athletes will train with portions that are long enough and there are usually one that can train 3 times a day. Therefore, it is possible for athletes who are accustomed to strenuous training will regulate their lifestyle, especially the problem of ideal body.

A simple way to get used to a healthy and clean lifestyle during this pandemic is to apply hand washing using soap [11]. It is highly recommended to always wash your hands 
with soap before doing activities. If there is no running water, you can use a hand sanitizer to replace the running water. Maintaining a healthy lifestyle today is not only towards an ideal body, but also maintains a healthy body so that it is not attacked by viral diseases. People who do not do enough physical activity are at twice the risk of heart disease when compared to people who do not active [12].

The nature of human physical fitness tends to decrease accordingly getting older. Naturally humans will grow old, so too with physical fitness, gradually the function of the organs of the body will decreasing and finally it doesn't work or matt at all [13]. This reduction process is overcome by maintaining a dynamic healthy lifestyle, namely regulating the rhythm of life that is balanced between physical needs and demands spiritual so as not to cause significant stress in life.

Sports activities greatly affect a person's physical fitness, moreover, these activities contribute directly to the components of physical fitness [14]. The importance of one's physical fitness should get very much attention. Therefore, self-awareness is needed to maintain a healthy lifestyle by regularly exercising and eating nutritious foods for all ages.

\section{Fitness activities for children}

Children are the buds of the nation that are growing and developing so that they become hope as the next generation in the future. One of the efforts to prepare candidates succession is through sporting activities. Sport is one of the means for improving human resources. This we must realize the benefits of exercise through the results that can be felt when someone does sports activities. We better be doing sports activities from an early age. Primary school age children (6-12 years) who have started. Having various kinds of activities both at school and outside of school requires conditions a body that is always in shape.

According to Djoko Pekik fitness related to physical is ability a person to be able to do daily work efficiently without fatigue excessive so that you can still enjoy your free time. Still according to fitness classified into three, namely :

1. Static fitness: the state of a person who is free from diseases and disabilities or is called

healthy.

2. Dynamic fitness: The ability of a person to work efficiently that is not require special skills.

3. Motor fitness: The ability of a person to work efficiently is demanding special skill.

Physical fitness or physical fitness is a condition in which a person performs a task or physical work and do not feel tired while doing the work or task. So being fit is not the same as being healthy. Someone who feels healthy is not necessarily fit. For doing one's job is not only required to be healthy but also have fitness because someone will be able to do a good job if not tired. There are several advantages when children have a good level of physical fitness among others:

1. increase children's learning capacity

2. increase resistance to disease

3. reduce the number of school absences. 
In connection with these several advantages, physical fitness is very necessary. Further benefits in the future for children who have good physical fitness after later maturity is :

1. Have a better performance

2. Have good health quality

3. Will be better prepared to face all the challenges of life

For that children must really pay attention to the level of physical fitness. Several things what must be considered so that physical fitness is maintained properly is to adjust the pattern eat, rest and exercise.

1. diet, namely by consuming healthy foods, in sufficient quantity as well the quality.

2. rest, namely maintaining a balance between performance and rest so that the recovery process or the original return period goes well so that the body will get back in shape after break

3. exercising, namely doing exercise regularly, measured and in accordance with the goals or the goal of the sport. So that it can be safely and effectively improve fitness.

\section{AEROBIC FITNESS EXERCISES FOR CHILDREN}

Before we get into aerobic fitness training, it's good to know what it is practice. Exercise is a conscious process of refining athletes to achieve something maximum performance by being given physical, tactical and mental burdens on a regular, targeted, increasing, gradually, and repeatedly in time. Another definition about exercise according to Rusli Lutan is a physical activity that is planned, structured, and carried out in the form of repetition of body movements with the intention of perfecting, or maintains one or more components of physical fitness. fitness training is a process systematically through stimulation of motion, aiming at the body, which includes the quality of the endurance of the heart, strength, and muscle endurance, flexibility and body composition. While Aerobic fitness is a measure of the heart's ability to pump oxygen-rich blood to it

Other parts of the body and the ability to adapt and recover from physical activity. From the three definitions above, the meaning of aerobic fitness training is a physical activity that is planned, structured and carried out in the form of repetition of movements body with a view to increasing or maintaining the quality of functional abilities the heart to pump oxygen-rich blood to other parts of the body and its ability to adjust and recover from physical activity. So to get a level of fitness The optimal body must compose a systematic, measured, and orderly training in order to exercise aerobic fitness is more effective.

Aerobic fitness training will stimulate the heart muscles. By increasing strong heart muscle, the blood pumped from the heart will be more so that it supplies oxygen throughout the body will be more too. But in applying fitness exercises aerobics must pay attention to the rules so that things that are dangerous do not happen. The thing that the main concern is who is doing aerobic and fitness exercises the purpose of the exercise. There are three goals of aerobic fitness training, namely: (1) a basic level aims to achieve a dynamic health degree, (2) intermediate level which aims achieve a level of fitness to carry out sports activities, and (3) fitness for achievers aims to produce athletes who excel in sports. To improve fitness physical elementary school children are sufficient at basic level fitness goals, so it must be pay attention to the principles of fitness training as described in table 1 so that this does not happen overload, illness, etc. that are negative in nature. 
Table 1 Principles of aerobic fitness training

\begin{tabular}{|c|c|c|c|}
\hline $\begin{array}{l}\text { Component } \\
\text { Principle }\end{array}$ & $\begin{array}{l}\text { Fitness level } \\
\text { Basic }\end{array}$ & $\begin{array}{l}\text { Fitness level } \\
\text { medium }\end{array}$ & $\begin{array}{l}\text { Fitness level } \\
\text { achievement }\end{array}$ \\
\hline Frequency & $\begin{array}{l}3 \text { times per } \\
\text { week }\end{array}$ & $\begin{array}{l}3-5 \text { times per } \\
\text { week }\end{array}$ & 5-6 times per week \\
\hline Intensity & $\begin{array}{l}50 \%-60 \% \\
\text { Pulse } \\
\text { Maximum } \\
\text { pulse / minute }\end{array}$ & $\begin{array}{l}60 \%-70 \% \\
\text { Pulse } \\
\text { Maximum } \\
\text { pulse / minute }\end{array}$ & $\begin{array}{l}60 \%-90 \% \\
\text { Pulse } \\
\text { Maximum pulse / } \\
\text { minute }\end{array}$ \\
\hline Time & 30 minute & $40-60$ minute & $60-120$ minute \\
\hline Type & $\begin{array}{l}\text { Walk, jog, run, } \\
\text { game }\end{array}$ & $\begin{array}{l}\text { Walk, jog, run, } \\
\text { game, } \\
\text { competition between } \\
\text { class }\end{array}$ & $\begin{array}{l}\text { run, } \\
\text { competition } \\
\text { sports, } \\
\text { programs } \\
\text { practice, } \\
\text { competition } \\
\text { between classes / } \\
\text { schools }\end{array}$ \\
\hline $\begin{array}{l}\text { Loadi } \\
\text { ng } \\
\text { excess }\end{array}$ & $\begin{array}{l}\text { There's no } \\
\text { need for } \\
\text { children }\end{array}$ & $\begin{array}{l}\text { There must be } \\
\text { increase and } \\
\text { decreased load } \\
\text { and long rest }\end{array}$ & $\begin{array}{l}\text { There must be } \\
\text { increase and } \\
\text { decreased load and shor } \\
\text { rest }\end{array}$ \\
\hline $\begin{array}{l}\text { Kema } \\
\text { juan } \\
\text { Dan } \\
\text { kekhu } \\
\text { susan }\end{array}$ & $\begin{array}{l}\text { Develop on } \\
\text { your own }\end{array}$ & Programs vary & $\begin{array}{l}\text { Peningkatan } \\
\text { prinsip latihan }\end{array}$ \\
\hline
\end{tabular}

The characteristics of aerobic fitness training are movements involving large muscles, motion continuous and rhythmic, as well as the nature of aerobic motion. Aerobic fitness training methods various, but in principle it aims to train the ability of the lungs and heart to better at supplying oxygen. The methods are:

1. Interval is a form of aerobic fitness training by combining implementation load training with rest periods. For example, a child runs 2 minutes later rest 15 seconds and so on according to the training load given.

2. Fartlek is a form of aerobic fitness training by running at speed that is fickle. For example, a child sprints / sprints 15 seconds and then runs slow / jog 15 seconds and so on according to the training load given.

3. circuit is a form of exercise consisting of several posts where the form of movement is in each post is different. To find out how hard the exercise is given to children, it can be seen from the pulse maximum heart rate per minute. The way is to feel the carotid artery which is located neck and beats counted for one minute. Then compare the results calculations in the formula as follows :

Max DN = 220 - age

Table 2.The formula calculates the maximum heart rate per minute

For example, a 10 year old child will train fitness with an intensity of $60 \%$ the maximum pulse rate per minute for the child is:

DNmax $=220-10$ 
$=210$

Furthermore, the result of the reduction is multiplied by the intensity of the exercise so charged the result :

$80.60 \times 210=126$

So the maximum heart rate per minute of the child is 126 , if after finishing training the maximum pulse is calculated and the result exceeds that number then the training will be tough for the child.

\section{Fitness activities for the elderly}

\section{AEROBIC EXERCISE PROGRAM}

Useful aerobic exercise better for the health of the elderly meet the FITT criteria (frequency, intensity, time, type). The frequency is how often the activity is carried out, how many days of the week. Intensity is how hard an activity is done. Usually classified into intensity low, medium, and high. Time refers on duration, how long an activity is done in one meeting, while the type of activity is the type - the type of physical activity that is done. Type-types of physical activity in the elderly according to Kathy, covering aerobic exercise, strengthening of muscles (muscle strengthening), flexibility, and exercise balance.Aerobic exercise is a exercise to develop the heart lungs or cardiorespiratory resistance or frequent called its aerobic freshness is a dynamic activity, continuous, and involving large muscles. Sukadiyanto stated that aerobic exercise is a form of organ apparatus ability training the body in inhaling, transporting, and using the necessary oxygen during the activity.

\section{Conclusion}

To avoid contracting the Covid-19 virus, the Government has appealed to the public to always maintain cleanliness and lead a healthy lifestyle. Healthy lifestyle, namely by maintaining immunity by exercising. Awareness and discipline to practice a culture of healthy living must continue to be built and implemented. Good living habits need to be managed routinely so that they become a lifestyle that is settled for each individual. Consistency is the most important thing to maintain survival and productivity together in this pandemic. Maintaining a healthy lifestyle during a pandemic need to be done so that the immune system is strong and avoid viruses. To maintain a lifestyle, it can be applied by maintaining a diet, sleeping pattern, not stressing and exercising regularly. Implement health protocols by using masks, washing hands with soap, and maintaining distance when in crowds. Keep exercising regularly at home and maintain a diet so that the body remains ideal.

\section{References}

[1] Karo MB. Perilaku Hidup Bersih dan Sehat. (PHBS) Strategi Pencegahan Penyebaran Virus Covid19. In Prosiding Seminar Nasional Hardiknas. 2020 May 30; (Vol. 1, pp. 1-4): 1.

[2] Adliyani ZO. Pengaruh perilaku individu terhadap hidup sehat. Jurnal Majority. 2015 Jun 1; 4(7): 109.

[3] Widiastuti I. Pelayanan Badan Penyelenggara Jaminan Sosial (BPJS) Kesehatan Di Jawa Barat. Public Inspiration. Jurnal Administrasi Publik. 2017; 2(2):91-101: 92. 
[4] Palar CM, Wongkar D, Ticoalu SH. Manfaat latihan olahraga aerobik terhadap kebugaran fisik manusia. eBiomedik. 2015 Feb; 23;3(1): 317.

[5] Pane BS. Peranan Olahraga Dalam Meningkatkan Kesehatan. Jurnal pengabdian kepada masyarakat. 2015 Mar; 21(79):1-4.

[6] Setyaningsih W, Karim UN, Zakiyah Z, Novitasari L, Pertiwi H. Hidup Sehat Bagi Lansia Pada Era New Normal Pandemik Covid-19: Laporan Akhir Pengabdian Kepada Masyarakat.

[7] Ardiyanto A, Purnamasari V, Sukamto S, Setianingsih E. Analisis Perilaku Hidup Bersih dan Status Kebugaran Jasmani di Era Pandemi Covid-19 Dosen PGSD. Jendela Olahraga. 2020 Jul 15; 5(2):131-40.

[8] Atmadja TF, Yunianto AE, Yuliantini E, Haya M, Faridi A, Suryana S. Gambaran sikap dan gaya hidup sehat masyarakat Indonesia selama pandemi Covid-19. AcTion: Aceh Nutrition Journal. 2020 Nov 13; 5(2):195-202.

[9] Ashadi K, Andriana LM, Pramono BA. Pola aktivitas olahraga sebelum dan selama masa pandemi covid-19 pada mahasiswa fakultas olahraga dan fakultas non-olahraga. Jurnal SPORTIF: Jurnal Penelitian Pembelajaran. 2020 Dec 12; 6(3):713-28.

[10] Intan T, Hasanah F, Wardiani SR, Handayani VT. Peningkatan Kualitas Hidup Di Masa Pandemi Covid-19 dengan Penerapan Pola Hidup Sehat. Jurdimas (Jurnal Pengabdian Kepada Masyarakat) Royal. 2021 Jan 11; 4(1):27-32.

[11] Safitri HI, Harun H. Membiasakan pola hidup sehat dan bersih pada anak usia dini selama pandemi Covid-19. Jurnal Obsesi: Jurnal Pendidikan Anak Usia Dini. 2020 Jun 27; 5(1):385-94.

[12] Kholis MN. Menjaga kebugaran jasmani dan imunitas sebagai pemutus mata rantai covid-19. Journal of Physical Activity (JPA). 2021 Feb 1;2(1):8-17.

[13] Sumintarsih S. Prinsip-Prinsip dan Program Latihan Meningkatkan Kebugaran Jasmani. In Proceeding Seminar Nasional membangun Insan Yang Berkarakter dan Bermartabat Melalui Olahraga 2012; (No. 1, pp. 425-434). Program Pasca Sarjana UNY.

[14] Prativi GO. Pengaruh Aktivitas Olahraga terhadap Kebugaran Jasmani. Journal of Sport Science and Fitness. 2013; 2(3). 